\title{
Rare and threatened vascular plants of the railways in Slovakia
}

\author{
Jana Májeková ${ }^{*}$, Dominik Roman Letz ${ }^{1}$, Michal Slezák ${ }^{1,2}$, \\ Marica Zaliberová ${ }^{1} \&$ Richard Hrivnák $^{1}$
}

${ }^{1}$ Institute of Botany, Slovak Academy of Sciences, Dúbravská cesta 9, 84523 Bratislava, Slovak Republic

${ }^{2}$ Catholic University, Faculty of Education, Hrabovská cesta 1, 03401 Ružomberok, Slovak Republic

* corresponding author (e-mail: jana.majekova@savba.sk)

\begin{abstract}
The paper presents data on the occurrence and secondary spreading of rare and threatened vascular plant species in railway habitats of Slovakia. We recorded 17 threatened vascular plant species and other 9 species that we considered to be rare in Slovakia. They grew at railway stations, mainly directly in the rail yard and also at the platforms or other similar facilities. Records of further 39 species were excerpted from literature sources. More native thermophilous species were represented among the recorded species as railway substrates provide suitable conditions for their growth. Also some archaeophytic segetal species were found quite frequent in the studied biotopes due to spreading of their seeds together with cereals transported by trains. Various habitats of railway transport facilities often provide suitable conditions for the secondary occurrence and further spreading not only of synanthropic or adventive, but also of rare and threatened plant species.
\end{abstract}

Key words: archaeophyte, distribution, native species, threatened species, platform, railway station, rail yard

\section{Introduction}

Railway represents a specific, man-made habitat in the landscape which provides suitable conditions for potential establishment, growth and spreading of plant species. Its environmental conditions support coexistence of different plant functional groups. Stony and well-drained substrates of sunny-exposed sites usually host an abundant set of dry-mesic and light-demanding species. Overall floristic spectrum is strongly affected by mass effect, i.e. several meadows and wetland species together with synanthropic plants typical of adjacent treeless vegetation can penetrate on rail embankments or directly in rail yards. Although their persistence is most often addressed to competition abilities, they undoubtedly belong to important floristic elements of such sites. Railway has great importance for spreading of adventive species (ferroviatic agestochory). Many seeds can be transferred with transported goods, mainly with cereal grains. Thus, segetal or many alien species grow on railway stations, especially in the area of holding tracks (Frantová 1947; Brandes 1993; Jehlík 1998).
Vegetation and floristic research of railway lines and stations has been only occasionally performed in Slovakia. The first studies were conducted during 1940s. While Futák (1943) pointed out a secondary origin of Linum austriacum on the railway in the Kremnické vrchy Mts., Schidlay (1944) focused on the spreading of Erucastrum nasturtiifolium and E. gallicum. Frantová (1947) reported several species on railway embankments and holding tracks in the surroundings of Trnava town. Interesting findings of some scarce species in railways across Slovakia (e.g. Eliáś 1979a, 1981; Jehlík \& Dostálek 2008; Jehlík et al. 2013; Májeková et al. 2013) were subsequently accompanied by vegetation studies (e.g. Eliáš 1977, 1979b, 1979c). There are also several local studies offering valuable information about synanthropic plants, including also those growing in railways (e.g. Kochjarová 2007; Letz et al. 2013). Recently, special attention was devoted to distribution patterns of new alien species Geranium purpureum in Slovak railway stations (Eliáš jun. 2011a; Zaliberová \& Májeková 2014; but see also Letz et al. 2013).

So far, the main attention in the research of the flora of railways has been paid to the synanthropic and 
adventive flora. No special or systematic research of the railway occurrences of rare and threatened species, originally occurring in natural or seminatural habitats, has been performed yet. Therefore the aim of this study was to monitor and evaluate rare and threatened vascular plant taxa in railway lines (or tramlines) and stations in Slovakia on the basis of our own field research as well as on the basis of literature sources.

\section{Material and methods}

The field research of railway habitats was carried out in Slovakia (Central Europe; $16^{\circ} 50^{\prime}-22^{\circ} 34^{\prime} \mathrm{E}$, $\left.47^{\circ} 44^{\prime}-49^{\circ} 37^{\prime} \mathrm{N}\right)$ mainly in the period of 2010-2014. We recorded only species (i) included in the Red list of ferns and flowering plants of Slovakia (Feráková et al. 2001) and (ii) rare in nature. The study region with the area of $49,035 \mathrm{~km}^{2}$ is characterized by marked altitudinal and climatic gradient that significantly affects species composition patterns of vascular plants. There are 69 railway lines throughout Slovakia (transport at 20 of them has recently been abandoned), including 946 railway stations and stops within them.

Phytosociological relevés were made according to the Zürich-Montpellier school (Braun-Blanquet 1964), using the modified 9-degree cover/abundance sampling scale (Barkman et al. 1964). The nomenclature of the plant taxa follows Marhold \& Hindák (1998); if not, they are cited with the author's name. Particular IUCN categories of threat are given according to Feráková et al. (2001).

List of recorded taxa is arranged alphabetically. Localities are given in the following order: $(i)$ number of the phytogeographical district or subdistrict according to Futák (1980): 1 - Burda, 2 - Ipel’sko-rimavská brázda, 4 - Záhorská nížina, 6 - Podunajská nížina, 8 - Východoslovenská nížina, 9 - Biele Karpaty, 13 - Strážovské and Súl'ovské vrchy, 14b - Vtáčnik, 14c - Kremnické vrchy, 14d - Pol'ana, 14e - Štiavnické vrchy, 14f - Javorie, 15 - Slovenské rudohorie, 16-Muránska planina, 17 - Slovenský raj, 21a - Malá Fatra (Lúčanská Fatra), 21b - Malá Fatra (Krivánska Fatra), 21c - Vel'ká Fatra, 22 - Nízke Tatry, 23b - Vysoké Tatry, 25 - Turčianska kotlina, 26a - Liptovská kotlina, 26b - Spišské kotliny, 27a - Biele Karpaty (severná čast'), 27b - Javorníky, 30c - Nízke Beskydy; (ii) name of town/village, more detailed location, altitude, number of square and subsquare of the grid mapping of the flora of Slovakia (Jasičová \& Zahradníková 1976), (iii) geographical coordinates, (iv) date, (v) author (DRL - Dominik Roman Letz, JM - Jana Májeková, MS - Michal Slezák, MZ - Marica Zaliberová, PM - Pavol Mered’a jun., RH - Richard Hrivnák).

Most of the voucher herbarium specimens are deposited either in the author's herbarium or in the herbarium of the Institute of Botany, Slovak Academy of Sciences in Bratislava, Slovakia (SAV). This information is given after the name of the author; if not, the species was noted only. Other stated herbarium acronyms follow Thiers (2014). Abbreviations: $\mathrm{N}$ - north, $\mathrm{S}$ - south, E - east, W - west.

The list of threatened and rare species was completed also with the literature data recorded in the area of Slovakia.

\section{Results}

In the railway facilities of Slovakia, we recorded 17 threatened vascular plant taxa (with the category of threat from LR:nt to EN) and 9 taxa that we considered to be rare in the country. The list of the recorded taxa with their location and short characteristic is following:

Adonis aestivalis (LR:nt) - It does not belong to typical species of railway flora, but its ecological affinity to man-made habitats is obvious (Futák 1982a). This naturalized archaeophyte (Medvecká et al. 2012) grows especially in vegetation of thermophilous annual weeds of cereal fields or vineyards on base-rich soils (Jarolímek et al. 1997; Lososová et al. 2009), but scattered occurrence has also been recorded in some Central European river ports (Jehlík 2013).

6; Vel'ká Maňa; railway station Maňa, in the rail yard, 130 m, 7875b; $48^{\circ} 09^{\prime} 22^{\prime \prime}, 18^{\circ} 16^{\prime} 15^{\prime \prime} ; 16.5 .2013$, PM.

Androsace elongata (VU) - This rare subcontinental thermophilous species of the flora of Slovakia is distributed mainly in the southern part of the country (cf. Hendrych \& Chrtek 1964). Current data on its occurrence in Central Slovakia (in the Slovenské stredohorie Mts.) are summarized in Slezák et al. (2012). Xerothermic neovolcanic rocky slopes represent one of the most typical habitats of this species in Slovakia. The secondary habitat reported here along railway is situated in the vicinity (ca $400 \mathrm{~m}$ ) of the natural occurrence of the species on andesite rocks south of the railway station of Kozárovce village.

6; Kozárovce; edge of the road near the railway, $\mathrm{S}$ of the railway station, $175 \mathrm{~m}, 7677 \mathrm{c} ; 48^{\circ} 18^{\prime} 28.52^{\prime \prime}, 18^{\circ} 32^{\prime} 02.41^{\prime \prime} ; 26.4 .2013$, DRL (SAV).

Carex distans (VU) - This sedge is known from almost whole Europe, except north-east and extreme north and from North Africa as well (Chater 1980; http://ww2. bgbm.org/EuroPlusMed). In Central Europe, Carex distans is a diagnostic species of (semi)saline grasslands and wet meadows of the Festuco-Puccinellietea class and Potentillion anserinae alliance (Chytrý \& Tichý 2003; Jarolímek et al. 2008; Borhidi et al. 2012; Kącki et al. 2013); our finding on railway embankments is exceptional.

14f; Lovinobaňa; railway station, railway embankments, direction to Lučenec, 239 m, 7583c; 48 26'30.0" $10^{\circ} 34^{\prime} 39.7^{\prime \prime}$; 13.6.2012, RH (SAV). 
Chamaepitys chia subsp. trifida (LR:nt) - The species is native to Mediterranean area and belongs among naturalized archaeophytes in Slovakia (Kmet'ová 1993; Medvecká et al. 2012). It grows on arable and abandoned fields, in vineyards, gardens, edges of roads and it prefers drier soils, rich in calcium. The species occurs in the warmest areas of Slovakia from the lowlands to colline belt (Smejkal 1961; Kmet'ová 1993). It is a characteristic taxon of the Caucalidion lappulae alliance (Jarolímek et al. 1997). The occurrence on the railway is only casual; it penetrated here probably from the surrounding fields. But the species was also recorded along railways in Upper Austria (Hohla et al. 2005).

6; Čachtice; railway station, $190 \mathrm{~m}, 7272 \mathrm{~d}$; 48 $43^{\circ} 24.4^{\prime \prime}$, $17^{\circ} 48^{\prime} 09.9^{\prime \prime}$; 12.6.2013, JM, MZ (SAV).

Chamerion dodonaei - It is a relatively rare chamaephyt with Submediterranean-Subatlantic-European distribution. Its natural occurrence is on river gravel deposits in alluvial areas in the communities of the Epilobion fleischeri alliance (Holub \& Kmet’ová 1988). Most localities of its occurrence are situated in the basin of the Váh river and it sporadically grows on gravel deposits of the Danube, Dunajec, Hornád, Kysuca, Orava, Poprad rivers and some other smaller flows (Slavík 1986; Holub \& Kmet’ová 1988; Jehlík 2013). It grows secondarily on stony banks, heaps and in stone pits. Recently, the species occurs also in railway stations where it sporadically creates dominant stands.

6; Bratislava; railway station Bratislava Východ, $132 \mathrm{~m}, 7869 \mathrm{a}$; 48 11'39.11", 17¹0'36.55"; 16.9.2013, DRL et al. (herb. DRL). - Pezinok; railway station, inter-track area, $150 \mathrm{~m}, 7769 \mathrm{~b}$; 4816'49.6", 17²16’01.8"; 11.6.2012, JM, MZ. - 13; Dolný Hričov; railway station, back hold yards, $315 \mathrm{~m}, 6777 \mathrm{~d} ; 49^{\circ} 14^{\prime} 34.1^{\prime \prime}$, 18³8'42.7"; 25.7.2012, JM, MZ: Relevé 1: area $15 \mathrm{~m}^{2}$, cover $\mathrm{E}_{\mathrm{t}}$ $85 \%, \mathrm{E}_{1} 80 \%, \mathrm{E}_{0} 15 \%$, height $90 \mathrm{~cm}$, substrate: railway gravel with scattered bigger stones. $\mathrm{E}_{1}$ : Chamerion dodonaei 4, Rubus caesius 1, Bromus sterilis + , Cirsium arvense + , Epilobium hirsutum,$+ E$. tetragonum + , Fallopia convolvulus + , Geranium robertianum + , Plantago lanceolata + , Senecio viscosus + , Taraxacum sect. $R u$ deralia + , Stellaria media r. $\mathrm{E}_{0}$ : Ceratodon purpureus $2 \mathrm{a}$, Bryum caespiticium + , Homalothecium lutescens + , Tortula ruralis + .

Chenopodium murale (LR:nt) - This species is commonly considered to be diagnostic and constant species of low-growing vegetation with dominance of prostrate annuals on nutrient-rich habitats (Malvion neglectae alliance) across Central Europe and the Balkan Peninsula (Mucina 1987; Lososová et al. 2009). Although an increasing number of new localities has been published from Slovakia in recent years (e.g. Letz et al. 2013), only a few of them were associated with railway stations. Current distribution area of the $C h$. murale remains still partially vague, as several historical records require revision.

2; Jesenské; railway station (Kochjarová 2010). - Lučenec; railway station (RH in Letz et al. 2013). - 6; Pezinok; railway station, ruins at the side of the station building, scarcely, $152 \mathrm{~m}, 7769 \mathrm{~b}$; $48^{\circ} 16^{\prime} 56.73^{\prime \prime}, 17^{\circ} 16^{\prime} 11.82^{\prime \prime}$; 9.9.2012, DRL (SAV). Surroundings of Trnava, freight stations (Frantová 1947). - Štúrovo, railway station (Eliáš jun. in Eliáš jun. 2010).

Dactylorhiza majalis (VU) - This perennial herb growing in Western and Central Europe represents the most abundant terrestrial orchid species in vegetation of wet meadows, fens and transitional mires (Wotavová et al. 2004; Hrivnák et al. 2006). It is able to settle habitats with various nutrient-supplies from lowlands to montane areas. In spite of its ecological plasticity, the presence in local moisture micro-depression along railway lines is occasional.

26a; Tatranská Štrba; railway station, moist edge of the platform in the NW part, $897 \mathrm{~m}, 6986 \mathrm{a} ; 49^{\circ} 05^{\prime} 03.47^{\prime \prime}, 20^{\circ} 03^{\prime} 52.56^{\prime \prime}$; 18.5.2013, MS (herb. MS).

Dalanum angustifolium - This xerothermophytic annual species grows mainly on calcareous soils, poor in humus. It is a pioneer species of skeletal soils with a small content of fine earth. Its eastern boundary of distribution passes through Slovakia (Peniašteková 1993). It is a diagnostic species of the Stipion calamagrostis alliance in the natural vegetation (Jarolímek et al. 2008). However, it grows also in the presence of Dauco-Melilotion species in man-made sites (Valachovič 1990). In recent decades, it has also spread into the railway stations and yards and river ports in the surrounding countries (Jehlík 2013; Letz et al. 2013; Galera et al. 2014).

13; Trenčianska Teplá; railway station, $1^{\text {st }}$ track, $224 \mathrm{~m}, 7074 \mathrm{~d}$; 48 $56^{\prime} 15.1^{\prime \prime}, 18^{\circ} 06^{\prime} 45.7^{\prime \prime}$; 14.6.2012, JM, MZ. - Ilava; railway station, $238 \mathrm{~m}, 6975 \mathrm{c} ; 49^{\circ} 00^{\prime} 08.0^{\prime \prime}, 18^{\circ} 14^{\prime} 12.3^{\prime \prime} ; 24.7 .2012$, JM, MZ (SAV). - Predmier; railway station, rail yard, $302 \mathrm{~m}, 6877 \mathrm{a}$; 49 ${ }^{\circ} 1^{\prime} 50.7^{\prime \prime}, 18^{\circ} 32^{\prime} 08.7^{\prime \prime}$; 25.7.2012, JM, MZ. - 14d; Zvolen; rail yard. - Vlkanová; railway station, rail yard (DRL in Letz et al. 2013). - 21a; Žilina; railway station, rail yard, $332 \mathrm{~m}, 6778 \mathrm{c} ; 49^{\circ} 13^{\prime} 38.7^{\prime \prime}$, 1844'39.4"; 25.7.2012, JM, MZ. - 22; Banská Bystrica; city part Kostiviarska, railway station, rail yard (RH in Letz et al. 2013). - 25; Between Jazernica and Bodovice; rail yard (Bernátová in Eliáš jun. 2012a). - Príbovce; railway yard. - Martin; railway station, rail yard (RH in Letz et al. 2013). - 27a; Lysá pod Makytou, Strelenka; railway station, rail yard, $445 \mathrm{~m}, 6874 \mathrm{~b} ; 49^{\circ} 11^{\prime} 02^{\prime \prime}, 18^{\circ} 08^{\prime} 40^{\prime \prime} ; 2.8 .2014$, JM, MZ. - 27b; Krásno nad Kysucou; rail yard (DRL in Letz et al. 2013).

Dichodon viscidum (VU) - In the past, this facultative halophytic species was relatively frequent on mineral-rich natural and anthropogenic habitats. It became rarer after considerable changes in agriculture management and water regime in the country. Recently, this species could be occasionally found also on secondary habitats, including salted margins of roads and railways. Such occurrences considerably move the border of its rather Pannonian distribution to the north in Slovakia (cf. Letz 2012). A secondary occurrence in a railway station is documented also in northern part of the Czech Republic: railway station Ostroměř (coll. M. Ducháček 28.6.2004 PR, rev. DRL).

26a; Liptovský Mikuláš; railway station, in the rail yard, $572 \mathrm{~m}$, 6983b; 4905'27.87", 19³6'36.49"; 7.5.2011, DRL (SAV). 
Draba nemorosa (LR:nt) - This circumboreal, EuroAmerican species grows almost in whole Europe, except for some countries in North-East and the Mediterranean area (Tutin 1993). Slovakia is a country with relatively frequent occurrence of this species mainly in (semi-) thermophilous grasslands, rarely in sandy and rocky grasslands, balks and fallows, margins of arable lands, river banks, field roads, road and railway embankments (Peniašteková \& Kliment 2002). Primarily, the last mentioned man-made habitats as well as rail yards and railway platforms are typical habitats where the species expands in recent decades.

2; Lučenec; railway station, in the rail yard, $184 \mathrm{~m}, 7683 \mathrm{~d}$; 48²0'13.2", 19³9'58.7"; 27.4.2012, RH (SAV). - 14c; Horná Štubňa; railway station, in the rail yard, 585 m, 7179c; 48 49'51.6", $18^{\circ} 52^{\prime} 39.2^{\prime \prime}$; 25.4.2013, RH. - Kremnické Bane; railway station, in the rail yard, $775 \mathrm{~m}, 7279 \mathrm{c} ; 48^{\circ} 44^{\prime} 27.2^{\prime \prime}, 18^{\circ} 54^{\prime} 12.2^{\prime \prime} ; 25.4 .2013$, RH. - 14d; Banská Bystrica; railway station, 343 m, 7281c; 48 44'10.1", 19¹0'09.0"; 28.5.2013, RH (SAV). - Vlkanová; railway station, $315 \mathrm{~m}, 7380 \mathrm{~b} ; 48^{\circ} 40^{\prime} 07.8^{\prime \prime}, 1^{\circ} 08^{\prime} 58.9^{\prime \prime}$; 28.5.2013, RH (SAV). - Sliač; railway station Sliač kúpele, at the platforms, 298 m, 7380d; 48³6'51.4", 1908'58.7"; 24.4.2013, RH. - Zvolen; railway station, $281 \mathrm{~m}, 7480 \mathrm{~b} ; 48^{\circ} 34^{\prime} 07.6^{\prime \prime}, 1^{\circ} 07^{\prime} 09.8^{\prime \prime} ; 10.5 .2010$, 18.4.2011, RH (SAV). - Zvolen; freight railway station, in the rail yard, $290 \mathrm{~m}, 7480 \mathrm{~b} ; 48^{\circ} 34^{\prime} 22.4^{\prime \prime}, 1^{\circ} 08^{\prime} 32.3^{\prime \prime} ; 3.5 .2012$, RH (SAV). - Zvolenská Slatina; railway station, platform, $331 \mathrm{~m}, 7481 \mathrm{~b}$; 4833'32.0", 19¹5'39.5'; 4.5.2012, RH. - Vígl'aš; railway station, at the platforms, $342 \mathrm{~m}, 7481 \mathrm{~b} ; 48^{\circ} 33^{\prime} 14.8^{\prime \prime}, 19^{\circ} 16^{\prime} 59.2^{\prime \prime}$; 4.5.2012, RH. - Pstruša; railway station, at the platforms, $347 \mathrm{~m}, 7481 \mathrm{~b}$; 48³3'11.6", 19¹8'47.0"; 3.5.2012, RH. - 14e; Banská Štiavnica; railway station, in the rail yard, $520 \mathrm{~m}, 7579 \mathrm{~d} ; 48^{\circ} 26^{\prime} 50.5^{\prime \prime}$, 1854'55.8"; 22.5.2013, RH, MS (SAV). - Banská Belá; railway station, in the rail yard, $462 \mathrm{~m}, 7579 \mathrm{~b} ; 48^{\circ} 28^{\prime} 27.4^{\prime \prime}, 18^{\circ} 56^{\prime} 48.7^{\prime \prime}$; 22.5.2013, RH, MS (SAV). - 14f; Lovinobaňa; railway station, at the platforms, $238 \mathrm{~m}, 7583 \mathrm{c}$; 48²6'42.0", 19³4'29.3"; 27.4.2012, RH. - Kriváň; railway station, 399 m, 7482d; 48³1'42.8", $19^{\circ} 26^{\prime} 42.5^{\prime \prime}$; 24.5.2011, 11.5.2012, RH (SAV). - Stožok; railway station, at the platforms, $360 \mathrm{~m}, 7482 \mathrm{c} ; 48^{\circ} 32^{\prime} 17.5^{\prime \prime}, 1^{\circ} 21^{\prime} 28.1^{\prime \prime}$; 2.5.2012, RH. - Detva; railway station, at the platforms, $375 \mathrm{~m}$, 7482c; 4832'01.6", 19²4'22.1"; 14.4.2014, RH. - 15, Hnúšt’a, rail yard in the edge of the railway station, $301 \mathrm{~m}, 7485 \mathrm{~b} ; 48^{\circ} 34^{\prime} 41.44^{\prime \prime}$, 1957'25.39"; 25.5.2013, MS (herb. MS). - Rimavská Baňa; railway station, in the rail yard, $256 \mathrm{~m}, 7485 \mathrm{~d}$; 48 $30^{\prime} 38.0^{\prime \prime}, 1^{\circ} 56^{\prime} 42.1^{\prime \prime}$; 31.5.2013, MS (herb. MS). - 16; Červená Skala; railway station, in the rail yard, $783 \mathrm{~m}, 7186 \mathrm{~d} ; 48^{\circ} 49^{\prime} 33.7^{\prime \prime}, 20^{\circ} 07^{\prime} 41.5^{\prime \prime} ; 16.6 .2004$, MZ; 48 49'20.95", 2007'55.08"; 25.5.2013, MS (herb. MS). Muráń; railway station, $386 \mathrm{~m}, 7286 \mathrm{c}$; 48 $44^{\prime} 26.6^{\prime \prime}, 20^{\circ} 03^{\prime} 05.0^{\prime \prime}$; 18.6.2004, MZ. - Tisovec; railway station, scattered in the rail yard, $434 \mathrm{~m}, 7385 \mathrm{~b} ; 48^{\circ} 41^{\prime 2} 24.75^{\prime \prime}, 1^{\circ} 56^{\prime} 09.76^{\prime \prime} ; 31.5 .2013$, MS (herb. MS). - 17; Vernár; railway station, gravel platform, 929 m, 7187a; 48 52'55.95", 20¹4'12.4"; 25.5.2013, MS (herb. MS). -22 ; Telgárt; railway station, platform in front of the main building, $864 \mathrm{~m}, 7187 \mathrm{c} ; 48^{\circ} 50^{\prime} 23.51^{\prime \prime}, 20^{\circ} 11^{\prime} 10.55^{\prime \prime} ; 25.5 .2013$, MS (herb. MS). - 23b; Starý Smokovec; railway station, in the rail yard, $993 \mathrm{~m}, 6887 \mathrm{c} ; 49^{\circ} 08^{\prime} 21.41^{\prime \prime}, 20^{\circ} 13^{\prime} 24.31^{\prime \prime} ; 29.5 .2013$, MS (herb. MS). - Tatranská Lomnica; railway station, at the platforms, 850 m, 6887b; 4909'52.62", 20¹6'45.78"; 29.5.2013, MS (herb. MS). - 25; Kláštor pod Znievom; railway station, at the platforms, 442 m, 7079a; 4857'22.8", 1851'09.2"; 25.4.2013, RH. - Malý Čepčín; railway station, in the rail yard, $463 \mathrm{~m}, 7079 \mathrm{c}$; 48 $54^{\prime} 14.7^{\prime \prime}$, 18 50'36.7"; 13.5.2012, RH (SAV). - Príbovce-Rakovo; railway station, at the platforms, $422 \mathrm{~m}, 7079 \mathrm{a}$; 48 $59^{\prime} 37.4^{\prime \prime}, 18^{\circ} 52^{\prime} 46.5^{\prime \prime}$; 5.5.2011, DRL (herb. DRL); 13.5.2012, RH (SAV). - Turčianske Teplice; railway station, in the rail yard, $491 \mathrm{~m}, 7179 \mathrm{a} ; 48^{\circ} 52^{\prime} 32.19^{\prime \prime}$,
1851'2.65"; 5.5.2011, DRL (herb. DRL). - Borcová; rail yard (Bernátová in Eliáš jun. 2012a). - 26a; Králova Lehota; railway station, scattered on the gravel embankment of the platform, 656 m, 6984d; 4901'33.98", 1947'08.6"; 14.5.2013, MS (herb. MS). - Liptovský Mikuláš; railway station, in the rail yard, $572 \mathrm{~m}$, 6983b; 4905'27.87", 19³6'36.49"; 7.5.2011, DRL (herb. DRL). - Ružomberok; railway station, rare in the freight rail yard, $480 \mathrm{~m}$, 6981b; 4904'56.24", 19¹8'39.48"; 7.5.2011, DRL (herb. DRL); 9.5.2013, MS (herb. MS). - Tatranská Strba; railway station, in the rail yard, $896 \mathrm{~m}, 6986 \mathrm{a}$; 4904'59.47", 2004'00.33"; 18.5.2013, MS (herb. MS). - Važec, railway station, gravel substrate of the rail yard, $811 \mathrm{~m}, 6985 \mathrm{~b} ; 4^{\circ} 04^{\prime} 01.21^{\prime \prime}, 19^{\circ} 59^{\prime} 17.51^{\prime \prime} ; 18.5 .2013$, MS (herb. MS). - Východná; railway station, in the rail yard, $753 \mathrm{~m}, 6985 \mathrm{~b}$; 49 $03^{\prime} 05.68^{\prime \prime}, 19^{\circ} 55^{\prime} 10.98^{\prime \prime} ; 14.5 .2013$, MS (herb. MS). - 26b; Svit; railway station, rare in the rail yard and on the unpaved substrate of the platforms, $731 \mathrm{~m}, 6987 \mathrm{a} ; 49^{\circ} 03^{\prime} 39.58^{\prime \prime}, 20^{\circ} 11^{\prime} 53.03^{\prime \prime}$; 18.5.2013, MS (herb. MS). - 28; Varín; railway station, in the rail yard, E of the station building, $355 \mathrm{~m}, 6879 \mathrm{a} ; 49^{\circ} 12^{\prime} 03.7^{\prime \prime}, 18^{\circ} 51^{\prime} 01.1^{\prime \prime} ;$ 5.5.2011, DRL (herb. DRL).

Erysimum marschallianum - This xerothermophilous species is originally distributed in Central and Eastern Europe; however, the status of its native occurrence in some localities is uncertain. In some countries (e.g. Poland), it is reported as introduced (Jalas \& Suominen 1994). Also in Slovakia, most of the recorded localities of this rare species are anthropogenic and a lot of them show certain dependence of the species on railway stations (cf. Michalková 2002). Recently, it has been recorded from the railway stations only (Letz et al. 2013). The origin of this species in Slovakia is not clear and a possibility of its previous introduction to the country is probable.

14e; Žiar nad Hronom; railway station (DRL in Letz et al. 2013). 15; Jaklovce; railway station (Feráková 2000 SAV sec. Michalková 2002). - Nálepkovo; railway station (Mráz 1998 herb. Mráz sec. Michalková 2002). - 21a; Žilina; railway station (Urbanová 1992 ZAM sec. Michalková 2002). - 30c; Bardejov; railway station, beside the rail yard, $267 \mathrm{~m}, 6793 \mathrm{~b}$; 49 $17^{\prime} 53.52^{\prime \prime}, 21^{\circ} 16^{\prime} 59.90^{\prime \prime}$; 26.5.2011, DRL (herb. DRL).

Erysimum repandum (VU) - The species is native to Europe and Asia with secondary occurrence in Australia and North America (Michalková 2002). Medvecká et al. (2012) evaluate it as a naturalized archaeophyte for Slovakia. Formerly, it was considered to be a typical segetal species, but nowadays it grows also on different ruderal habitats, such as fallows, surroundings of roads, dumps, and banks. It has also been recorded in some river ports (Jehlík 2013). E. repandum is a thermophilous species with the centre of its occurrence in lowland to colline belt (Michalková 2002). It spreads to railway biotopes either from fields or with transported cereals.

6; Boleráz; railway station, $182 \mathrm{~m}, 7571 \mathrm{a} ; 48^{\circ} 28^{\prime} 15.1^{\prime \prime}, 17^{\circ} 29^{\prime} 52.5^{\prime \prime}$; 12.6.2012, JM, MZ (SAV). - Leopoldov; railway station, holding tracks, $143 \mathrm{~m}, 7572 \mathrm{~d}$; 48 $26^{\prime} 25.0^{\prime \prime}, 17^{\circ} 45^{\prime} 28.8^{\prime \prime} ; 12.6 .2012$, JM, MZ (SAV). -8 , Čierna nad Tisou, railway station; Dobrá, rail transhipment yard (Jehlík \& Dostálek 2008).

Geranium lucidum - This Subatlantic-Submediterranean species is distributed mainly in Western and 
Southern Europe. Northern border of its distribution area passes through south-western Slovakia (cf. Meusel et al. 1978). Only recently, one locality was found in south-eastern central Slovakia (at Bretka village; Sutorý 2013). In Slovakia, this rare species grows mostly on shady andesitic or limestone rocky places. Its occurrence has not been previously known on a secondary habitat. The railway station of Dražovce is located close to the phytogeographical district of Tríbeč, where several natural localities of the species were reported (cf. Jasičová 1982).

6; Dražovce; railway station, in the rail yard, $150 \mathrm{~m}, 7674 \mathrm{a}$; $48^{\circ} 21^{\prime} 27^{\prime \prime}, 18^{\circ} 03^{\prime} 15^{\prime \prime} ; 16.5 .2013$, PM.

Geranium molle (LR:nt) - This xerothermophilous species is distributed mainly in Western, Southern and Central Europe and Northern Africa (cf. Meusel et al. 1978). It is quite rare in Slovakia, distributed especially in southern part of the country, growing rather on seminatural habitats (Jasičová 1982). However, its localities are insufficiently documented.

4; Jablonica; railway station, in the rail yard, $200 \mathrm{~m}, 7370 \mathrm{c}$; $48^{\circ} 36^{\prime} 24^{\prime \prime}, 17^{\circ} 24^{\prime} 32^{\prime \prime}$; 6.5.2013, I. Hodálová, PM.

Geranium rotundifolium (VU) - This Mediterranean to Submediterranean thermophilous species is distributed mainly in Southern Europe, Northern Africa and in adjacent Western Asia (cf. Meusel et al. 1978). Northern border of its distribution area passes through the northern margin of the southern half of the territory of Slovakia (cf. Slezák et al. 2012), where it prefers rather natural or seminatural habitats like rocky bushy slopes with granodioritic, andesitic or limestone bedrock. Records from railway stations presented here document a certain tendency of this rare species to be introduced to secondary habitats. Similar occurrence of the species and its spreading along railways to the north in recent years is documented also from the Czech Republic (cf. Hadinec 2014).

4; Kuchyňa; railway station, in the rail yard, $220 \mathrm{~m}, 7568 \mathrm{~d}$; 48 $24^{\prime} 47^{\prime \prime}, 17^{\circ} 08^{\prime} 13^{\prime \prime}$; 6.5.2013, I. Hodálová, PM (foto). - 6; Vráble; railway station, in the rail yard, $140 \mathrm{~m}, 7775 \mathrm{~b} ; 48^{\circ} 15^{\prime} 10^{\prime \prime}, 18^{\circ} 18^{\prime} 01^{\prime \prime}$; 16.5.2013, PM (SAV). - Zlaté Moravce; railway station, at the S margin of the station building, $180 \mathrm{~m}, 7676 \mathrm{a} ; 48^{\circ} 23^{\prime} 08^{\prime \prime}, 18^{\circ} 22^{\prime} 36^{\prime \prime}$; 16.5.2013, PM (SAV).

Hippochaete ramosissima - Typical species growing in dry to wet sandy habitats of lowlands in southern part of Slovakia with secondary spreading into manmade or man-modified habitats such as railways, gravel yards or road margins (Futák et al. 1966; Smatana 2004; Smatana in Eliáš 2011b). It is a diagnostic species of Festucetea vaginatae and Koelerio-Corynephoretea classes (Jarolímek et al. 2008).

6; Bratislava; railway station Bratislava Východ, $132 \mathrm{~m}, 7869 \mathrm{a}$; $48^{\circ} 11^{\prime} 39.11^{\prime \prime}, 17^{\circ} 10^{\prime} 36.55^{\prime \prime} ; 16.9 .2013$, DRL et al. (herb. DRL). - Sládkovičovo; edge of the railway embankment $\mathrm{W}$ of the railway station, $117 \mathrm{~m}, 7871 \mathrm{~b}$; 48¹1'46.7', 17³7'28.8'; 4.6.2014, DRL. - Galanta; in the rail yard $\mathrm{W}$ of the railway station, near the branching-off to Sered', $117 \mathrm{~m}, 7872 \mathrm{a} ; 48^{\circ} 11^{\prime} 09.3^{\prime \prime}, 17^{\circ} 42^{\prime} 55.6^{\prime \prime}$; 4.6.2014, DRL. - Trnovec nad Váhom; in the rail yard E of the railway station, $114 \mathrm{~m}, 7873 \mathrm{~b}$; 4809'06.0”, 1756'07.5”; 4.6.2014, DRL. - Palárikovo; near the branching-off to Nové Zámky, in the rail yard, $114 \mathrm{~m}, 7974 \mathrm{~b}$; 4803'19.0”, 1805'17.5”; 4.6.2014, DRL. - Levice; $\mathrm{S}$ of the railway station, near the branching-off to Bratislava, in the rail yard, $156 \mathrm{~m}, 7777 \mathrm{~d} ; 48^{\circ} 12^{\prime} 21.2^{\prime \prime}, 18^{\circ} 35^{\prime} 43.0^{\prime \prime}$; 2.5.2014, DRL. - Bratislava; main railway station, in the rail yard ca $300 \mathrm{~m}$ E of the station, $168 \mathrm{~m}, 7868 \mathrm{~b} ; 48^{\circ} 09^{\prime} 31.0^{\prime \prime}, 17^{\circ} 06^{\prime} 37.0^{\prime \prime}$; 4.6.2014, DRL.

Lactuca saligna (EN) - This Eurasiatic-sub-Mediterranean species is known from substantial part of Europe and its distribution area extends as far as $52^{\circ}$ north latitude. It is typical lowland to sub-mountain species of artificial or man-modified natural habitats such as pastures, river banks, wood margins, arable fields; on the other hand, it can be found in strictly artificial habitats such as margin of railways or roadsides (Feráková 1977). In Slovakia, Lactuca saligna belongs to a relatively rare and threatened species (cf. Feráková et al. 2001) considered a diagnostic species of saline pastures (Jarolímek et al. 2008). However, many new localities from man-made or man-modified habitats have chronologically increased in recent years (Kochjarová 2010; Eliáš jun. in Eliáš jun. 2013). Based on this evidence, category of threat of the species will decline in the new version of the Slovak Red list of vascular plant on category "vulnerable" (Eliáš et al. 2014).

2; Lučenec; railway station, in the rail yard, $184 \mathrm{~m}, 7683 \mathrm{~d}$; 48 20'13.2", 19³9'58.7"; 31.7.2012, RH (SAV). - 14d; Zvolen; railway station, at the $1^{\text {st }}$ platform, $282 \mathrm{~m}, 7480 \mathrm{~b} ; 48^{\circ} 34^{\prime} 12.9^{\prime \prime}$, $19^{\circ} 07^{\prime} 17.5^{\prime \prime}$; 30.7.2012, RH (SAV). - 14f; Kriváń; railway station, 399 m, 7482d; 48³1'42.8", 19²6'42.5"; 2.7.2013, RH (SAV).

Neslia paniculata - It is an Asiatic species with distribution in almost whole Europe (Mráz 2002). It is evaluated as a naturalized archaeophyte (Medvecká et al. 2012) and a characteristic species of the typical segetal thermophilous alliance Caucalidion lappulae (Jarolímek et al. 1997) in Slovakia. It occurs relatively rarely in arable fields (mainly in cereals) and other synanthropic habitats scattered in the whole area of Slovakia (Mráz 2002). It is spread probably with cereal grains along railways and also in river ports (Jehlík 2013).

6; Surroundings of Trnava; railway embankments (Frantová 1947).13; Trenčianska Teplá; railway station, holding tracks, 224 m, 7074d; 48 $56^{\prime} 15.1^{\prime \prime}, 18^{\circ} 06^{\prime} 45.7^{\prime \prime}$; 14.6.2012, JM, MZ (SAV).

Papaver argemone (VU) - The species is native to southern Europe and it behaves as a naturalized archaeophyte in Slovakia (Šípošová et al. 2002; Medvecká et al. 2012). It occurs mainly in cereal fields, fallows and different ruderal biotopes from lowland to colline belt. The centre of its distribution is in western and southern Slovakia, mostly in the Pannonian area (Šípošová et al. 2002). P. argemone is a relatively frequent weed in the fields in the Borská (Záhorská) nížina Lowland (Májeková et al. 2010; Májeková \& Zaliberová 2014). 
It is a characteristic species of the Centaureetalia cyani order which is typical for cereal fields (Jarolímek et al. 1997). Its occurrence in railway stations and lines is quite common, probably due to transport of cereal grains by railway traffic.

4; Šajdíkove Humence; railway station, 185 m, 7369b; 48³9’35.6”, $17^{\circ} 15^{\prime} 45.8^{\prime \prime} ; 30.6 .2011$, JM, MZ. - Jablonica; railway station, 205 m, 7370c; 48³6'22.1", 17²4’36.2"; 30.6.2011, JM, MZ. - Plavecký Stvrtok; railway station, beside the pavement, 159 m, 7668a; 48²2'19.5", 1700'26.3"; 11.5.2011, JM, MZ. - 6; Smolenice;

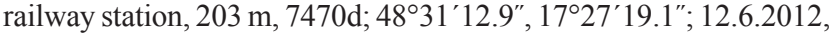
JM, MZ (SAV). - Leopoldov; railway station, holding tracks, 143

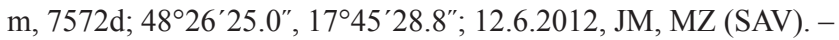
Čachtice; railway station, $190 \mathrm{~m}, 7272 \mathrm{~d}$; $48^{\circ} 43^{\prime} 24.4^{\prime \prime}, 17^{\circ} 48^{\prime} 09.9^{\prime \prime}$; 12.6.2013, JM, MZ (SAV). - Railway stations: Gáň, Sládkovičovo (Eliáš jun. in Eliáš jun. 2010). -13, Trenčianska Teplá; railway station, holding tracks, $224 \mathrm{~m}, 7074 \mathrm{~d} ; 48^{\circ} 56^{\prime} 15.1^{\prime \prime}, 1^{\circ} 06^{\prime} 45.7^{\prime \prime}$; 14.6.2012, JM, MZ (SAV).

Papaver dubium subsp. austromoravicum (LR:nt) - This Pontic-Pannonian taxon occurs in the Balkans, Hungary, Austria, Czech Republic, Slovakia and Ukraine (Hörandl 1994; Šípošová et al. 2002). Northern margins of its distribution area pass through Slovakia, where the species is known mainly in southern Slovakia, while more northern localities are very few. In addition to natural habitats such as xerophilous grasslands and shrubs, the taxon grows in man-made habitats, including vineyards and railway embankments (Š́pošová et al. 2002).

14b; Žiar nad Hronom; railway station, side tracks beside the line SW of the station building, $245 \mathrm{~m}, 7479 \mathrm{a}$; 48 34'37.07", 18 ${ }^{\circ} 52^{\prime} 01.51^{\prime \prime}$; 20.5.2013, DRL (herb. DRL). - 14d; Zvolen; freight railway station, in the rail yard, $290 \mathrm{~m}, 7480 \mathrm{~b} ; 48^{\circ} 34^{\prime} 22.4^{\prime \prime}, 19^{\circ} 08^{\prime} 32.3^{\prime \prime} ; 3.5 .2012$, RH (SAV). - 14f; Stožok; railway station, in the rail yard, $360 \mathrm{~m}$, 7482c; 4832'17.6", 19²1'27.9"; 24.5.2013, RH.

Petrorhagia saxifraga (LR:nt) - It is a perennial species with native occurrence in Southern and Central Europe. It grows in the warmest areas of Western and Southern Slovakia. Most localities are situated in the surrounding of the city of Bratislava (Štrba 2012), so the occurrence in railway facilities in this city is not surprising. It was recorded also in some Slovak (Bratislava and Komárno) and Austrian ports (Jehlík 2013). However, it primarily grows on dry, heating, calcareous, nutrient-poor biotopes and it is a diagnostic species of the Festucetea vaginatae class and of the Festucion vaginatae and Euphorbio cyparissiae-Callunion vulgaris alliances (Jarolímek et al. 2008; Štrba 2012).

6; Bratislava; port Dunajský prístav, railway in the area of the port, $136 \mathrm{~m}, 7868 \mathrm{~d} ; 48^{\circ} 08^{\prime} 17.98^{\prime \prime}, 17^{\circ} 07^{\prime} 49.87^{\prime \prime} ; 28.5 .2013$, excursion. - Bratislava; city part Ružinov, Ružinovská street, at the tram rails near the stop Súmračná, 136 m, 7869a; 4809'28.83", 17¹0'10.41"; 29.5.2013, DRL.

Saxifraga granulata (LR:nt) - This European (Subatlantic) perennial species reaches the eastern limit of its range in Slovakia (Hrouda 1999). Detailed analysis of its historical records (Jasičová \& Futák 1985) suggests its vegetation preference to mown meadows, mesic pastures and dry grasslands. Although most of the available localities occur primarily in Central Slovakia (e.g. Štiavnické vrchy Mts.), data from man-made sites are scarce.

14e; Kozelník; railway station, in the rail yard, $374 \mathrm{~m}, 7480 \mathrm{c}$; 48 30'55.41", 1900'16.97"; 22.5.2013, RH, MS (herb. MS).

Saxifraga tridactylites - This slender annual species naturally inhabits calcareous grasslands and various stony and gravel places, but many findings are closely related to anthropogenic sites. Large populations have been recently observed along railways and roadsides in Central Europe (Brandes 1983, 1993; Reisch 2007). The same is also true for Slovakia, where natural records (e.g. from different types of dry and sun-exposed stony habitats; Kliment et al. 2000, 2008) are accompanied by those originating from man-made habitats such as railway embankments, field roads, old walls or river ports (Jasičová \& Futák 1985; Jehlík 2013).

6; Bratislava-Vinohrady; railway station, $143 \mathrm{~m}, 7868 \mathrm{~b}$; 48 $11^{\prime} 13^{\prime \prime}$, $17^{\circ} 07^{\prime} 59^{\prime \prime} ; 16.4 .2012$, MZ. - Trnava; railway station, $1^{\text {st }}$ platform,

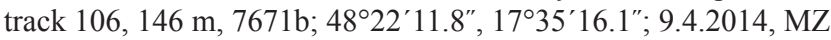
(SAV). - 9; Stará Turá; railway station, $280 \mathrm{~m}, 7272 \mathrm{a}$; 4846' 23.7", $17^{\circ} 42^{\prime} 01.2^{\prime \prime}$; 12.6.2013, JM, MZ (SAV). - 14e; Banská Belá; railway station, in the rail yard, $462 \mathrm{~m}, 7579 \mathrm{~b} ; 48^{\circ} 28^{\prime} 23.8^{\prime \prime}, 18^{\circ} 56^{\prime} 50.42^{\prime \prime}$; 22.5.2013, RH, MS (herb. MS). - 14f; Kriváň; railway station, 399 m, 7482d; 48 $31^{\prime} 42.8^{\prime \prime}, 19^{\circ} 26^{\prime} 42.5^{\prime \prime} ; 11.5 .2012$, RH (SAV). - 21c; Ružomberok; railway station, $477 \mathrm{~m}, 6981 \mathrm{~b}$; side tracks beside the parking, $477 \mathrm{~m}$; 4904'56.89", 19॰18'37.63"; 7.5.2011, DRL (herb. DRL); inter-track areas, 4904'57.7", 19¹8'37.18"; 9.5.2013, MS (herb. MS)

Sempervivum carpathicum subsp. heterophyllum (VU) - This Western Carpathian endemic taxon from the Sempervivum montanum group is distributed only in Slovakia. Its occurrence is restricted to andesite or rhyolite of neovolcanic mountains (Slovenské stredohorie and Slanské vrchy Mts.) or, very rarely, to autometamorphic granitic rocks at the southern foothills of the Krivánska Malá Fatra Mts. The altitude of natural habitats well-corresponds with the altitudinal range of the whole S. montanum group (Letz \& Marhold 1998; Letz 2002). The record of an occurrence on a secondary habitat of a railway wall, as well of rocks hewn during the construction of the railway documented here, is possible only due to the very close occurrence on natural autometamorphic granitic rock above the railway. The plants growing on the wall were collected already in 1978 by Hodoval (BRA, rev. DRL).

$21 \mathrm{~b}$; Between the villages Kral'ovany and Párnica; stony wall under the railway, $460 \mathrm{~m}, 6880 \mathrm{~b} ; 49^{\circ} 10^{\prime} 25.52^{\prime \prime}, 1^{\circ} 07^{\prime} 54.08^{\prime \prime} ; 15.7 .1993$, DRL.

Tribulus terrestris (EN) comes from Africa, but nowadays it occurs in all continents. In Slovakia, it is evaluated as a naturalized archaeophyte and the northern border of its archaeophytic distribution passes through Slovakia (Eliáš \& Feráková 1999; Medvecká et al. 2012). In the past, the species was relatively rare with distribution only in south-western Slovakia. Arable and 
abandoned fields, edges of roads and sands were typical habitats of its occurrence (Zahradníková 1982; Eliáš \& Feráková 1999). T. terrestris is a diagnostic species of the Eragrostion alliance (Jarolímek et al. 2008). Nowadays, it spreads very intensively by railway traffic to secondary habitats such as rail yards and platforms. Such occurrence was firstly recorded by Eliáš (1977) in Slovakia. It makes serious troubles to railway workers because of its thorny fruits. In the past, the species was protected by law in Slovakia but, at present, it is not under protection. Also its category of threat will be reduced (Eliáš et al. 2014). Our record of the species in the railway station of Trenčianska Teplá seems to be the most northern locality of its distribution in Slovakia; Zahradníková (1982) considered, as the most northern one, the occurrence in Sered'.

4; Kúty; railway station, behind the $5^{\text {th }}$ track, $160 \mathrm{~m}, 7368 \mathrm{a}$; 48³9'43.7", 1702'51.9"; 28.7.2011, JM, MZ (relevé 2). - Bratislava-Devínska Nová Ves; railway station (Feráková in Eliáš jun. 2010). - 6; Bratislava; railway station Bratislava Východ, $132 \mathrm{~m}$, 7869a; 48 $11^{\prime} 41.33^{\prime \prime}, 17^{\circ} 10^{\prime} 51.04^{\prime \prime}$ and 48 $11^{\prime} 41.79^{\prime \prime}, 17^{\circ} 10^{\prime} 35.07^{\prime \prime}$; 16.9.2013, DRL et al. (herb. DRL). - Bratislava; main railway station, holding tracks $\mathrm{W}$ of the main building, $178 \mathrm{~m}, 7868 \mathrm{~b}$; 48 $09^{\prime} 33.2^{\prime \prime}, 17^{\circ} 06^{\prime} 18.3^{\prime \prime}$; 28.7.2014, MZ. - Leopoldov; railway station, holding tracks, $143 \mathrm{~m}, 7572 \mathrm{~d} ; 48^{\circ} 26^{\prime} 25.0^{\prime \prime}, 17^{\circ} 45^{\prime} 28.8^{\prime \prime}$; 12.6.2012, JM, MZ (SAV). - Trnava; railway station, $2^{\text {nd }}$ platform, 146 m, 7671b; 48²2'11.6", 17³5'08.9"; 14.7.2014, MZ. - Railway stations: Sered', Bratislava-Nové Mesto (Eliáš 1977, 1979a). - Nitra; railway station (Košt’ál in Eliáš jun. 2014). - 13; Trenčianska Teplá; railway station, holding tracks, $224 \mathrm{~m}, 7074 \mathrm{~d} ; 48^{\circ} 56^{\prime} 15.1^{\prime \prime}$, $18^{\circ} 06^{\prime} 45.7^{\prime \prime} ;$ 14.6.2012, JM, MZ (SAV).

Relevé 2: area $7.5 \mathrm{~m}^{2}$, cover $\mathrm{E}_{1} 45 \%$, height $5-30 \mathrm{~cm}$, substrate: finer railway gravel. $\mathrm{E}_{1}$ : Tribulus terrestris 3, Bromus tectorum 1 , Setaria pumila 1, Amaranthus albus + , Arenaria serpyllifolia + , Bromus hordeaceus + , Digitaria sanguinalis + , Linaria vulgaris + , Portulaca oleracea + , Viola arvensis + .

Vicia grandiflora - This annual species inhabits warm and dry places such as meadows, steps, banks, vineyards, fields. Its occurrence is documented mainly in the Pannonian region and only rarely in the Carpathian region (Chrtková 1988). Therefore, the occurrence in the railway station located in the phytogeographical district of Vtáčnik is exceptional. However, its spreading by transport is probably common (Jehlík 2013).

6; Bratislava-Vinohrady; railway station, slope near the railway line, 143 m, 7868b; 48¹1'13", 1707'59"; 1995-2007, MZ. - 8; Vel'ké Kapušany; rail transhipment yard (Jehlík \& Dostálek 2008). - 14b; Žiar nad Hronom; railway station, side tracks beside line SW of the station building, $245 \mathrm{~m}, 7479 \mathrm{a} ; 48^{\circ} 34^{\prime} 37.07^{\prime \prime}, 18^{\circ} 52^{\prime} 01.51^{\prime \prime}$; 20.5.2013, DRL (herb. DRL).

Vulpia myuros - It is a thermophilous low grass with Submediterranean-Subatlantic-Eurasian distribution. It grows, primarily, on acidic substrates - granodiorites, slaty gneiss and acidic sands (Valachovič et al. 1995) and is a diagnostic species of the Thero-Airion alliance (Jarolímek et al. 2008). Secondary occurrence on the stony runes in vineyards of the Malé Karpaty Mts. was reported by Maglocký (1978), on the roadsides in the Tríbeč Mts. - by Eliáš (1972) and in the Borská nížina
Lowland - by Zaliberová et al. (2008). It spreads by railway and ship transport also in some European countries (Brandes 1983, 2003; Jehlík 2013).

6; Cífer; railway station, beside the panel road near the track, 148

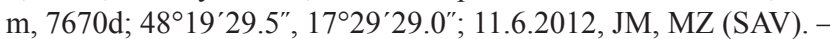
Čachtice; railway station, 190 m, 7272d; 48 43'24.4", 1748'09.9"; 12.6.2013, JM, MZ (SAV).

Excerpted records of other 39 threatened species (with categories DD to EX) from literature sources:

Aegilops cylindrica (CR): 1; Chl'aba; railway station (Eliáš jun. et al. 2013). - 6; Dunajská Streda; railway station (Eliáš 1981). - Railway stations: Dunajská Streda, Sered', Galanta, Trnovec nad Váhom (Eliáš jun. et al. 2013). - 8; Čierna nad Tisou; railway station; Dobrá, rail transhipment yard (Jehlík \& Dostálek 2008). - Railway stations: Dobrá, Čierna nad Tisou (Eliáš jun. et al. 2013).

Bromus arvensis (VU): 6; Surroundings of Trnava; railway embankments and in the rail yard (Frantová 1947). - 8; Čierna nad Tisou; railway station; Dobrá, rail transhipment yard (Jehlík \& Dostálek 2008).

Bromus secalinus (EN): 8; Čierna nad Tisou; railway station; Dobrá, rail transhipment yard (Jehlík \& Dostálek 2008).

Camelina rumelica (CR): 8; Čierna nad Tisou; railway station (Jehlík \& Dostálek 2008).

Caucalis platycarpos (VU): 6; Šurany; near the train-formation line (Eliáš 1979a).

Caucalis platycarpos subsp. platycarpos (VU): 6; Surroundings of Trnava; railway embankments and in the rail yard (Frantová 1947).

Cephalaria transsylvanica (LR:nt): 6; Railway stations: Šal'a, Hlohovec (Eliáš jun. in Eliáš jun. 2010).

Ceratocephala orthoceras (former EX): 8; Čierna nad Tisou; railway station (Májeková et al. 2013).

Chenopodium urbicum (VU): 8; Čierna nad Tisou; railway station; Dobrá, rail transhipment yard (Jehlík \& Dostálek 2008).

Chenopodium vulvaria (VU): 6; Surroundings of Trnava; freight railway stations (Frantová 1947).

Conringia orientalis (EN): 8; Čierna nad Tisou; railway station (Jehlík \& Dostálek 2008).

Corallorhiza trifida (VU): 23b; Railway embankment between stations Štrbské and Popradské Pleso (Májeková \& Podroužková Medvecká in Eliáš jun. 2011b).

Crepis pulchra (EN): 2; Hontianske Tesáre; railway station (Eliáš jun. in Eliáš jun. 2012a). - 6; Štúrovo; railway station (Eliáš jun. in Eliáš jun. 2011b). - Nitra; railway station (Eliáš jun. in Eliáš jun. 2012a).

Cyanus segetum (LR:nt): 6; Surroundings of Trnava; railway embankments and in the rail yard (Frantová 1947). - 8;Čierna nad Tisou; railway station (Jehlík \& Dostálek 2008). 
Eragrostis pilosa (EN): 14e; Žiar nad Hronom; railway station (Eliáš jun. in Eliáš jun. 2012a).

Eryngium planum (VU): 8; Čierna nad Tisou; railway station; Vel'ké Kapušany, rail transhipment yard (Jehlík \& Dostálek 2008).

Erysimum diffusum (LR:nt): 8; Čierna nad Tisou; railway station; Dobrá; rail transhipment yard (Jehlík \& Dostálek 2008).

Erysimum wittmannii: 21c; Horný Harmanec; railway station Harmanec-jaskyňa, inter-track area (Kochjarová 2007).

Galium tricornutum (EN): 8; Čierna nad Tisou; railway station (Jehlík \& Dostálek 2008).

Glaucium corniculatum (EN): 8; Čierna nad Tisou; railway station (Jehlík \& Dostálek 2008).

Herniaria hirsuta (LR:nt): 4; Kúty, railway station (more specimens sec. Eliáš jun. 2012b); Šajdíkove Humence; railway line (Dvořák 1963 BRA sec. Eliáš jun. 2012b).

Hibiscus trionum (VU): 8, Čierna nad Tisou, railway station (Jehlík \& Dostálek 2008).

Kickxia elatine (LR:nt): 8, Čierna nad Tisou, railway station (Jehlík \& Dostálek 2008).

Lepidium perfoliatum (VU): 6; Bratislava-Nové Mesto; railway station (Feráková \& Javorčíková 1974). - Sered'; railway station (Eliáš 1979a). - 8; Čierna nad Tisou; railway station (Jehlík \& Dostálek 2008).

Linum austriacum (LR:nt): 6; Surroundings of Trnava; railway embankments (Frantová 1947). - 10; Vad'ovce; railway embankment (Weber 1934 PRC sec. Futák 1982b). - 14c; Jalná; railway above the village (Futák 1934 SAV sec. Futák 1982b, Futák 1943). - 25; Malý Čepčín; railway (Margittai $1914 \mathrm{sec}$. Futák 1982b). - Kláštor pod Znievom; railway station (Petrikovich 1911 BRA et Margittai 1911 sec. Futák 1982b). - 29; Between the villages Krivany and Kamenica; at railway (Ščavnický 1967 sec. Futák 1982b).

Marrubium peregrinum (LR:nt): 6; Surroundings of Trnava; railway embankments (Frantová 1947).

Minuartia glomerata (EN): 6; Štúrovo; railway station (Eliáš jun. in Eliáš jun. 2010).

Misopates orontium (VU): 8; Čierna nad Tisou; railway station (Jehlík \& Dostálek 2008).

Nigella arvensis (VU): 6; Surroundings of Trnava; railway embankments and freight railway stations (Frantová 1947). - 8; Čierna nad Tisou; railway station (Jehlík \& Dostálek 2008).

Podospermum laciniatum (CR): 6; Surroundings of Trnava; railway embankments (Frantová 1947). This record could concern the more frequent and agestochorically spreading $P$. canum, as the two species were misinterpreted in some floras of former Czechoslovakia.

Psyllium arenarium (VU): 6; Railway stations: Bratislava Petržalka, Bratislava Východ, Trnava, Sered', Slažany (Eliáš 1979a, c). - Levice; railway station
(Eliáš jun. in Eliáś jun. 2010). - 8; Čierna nad Tisou, railway station; Dobrá, rail transhipment yard (Jehlík \& Dostálek 2008).

Rumex stenophyllus (VU): 8; Čierna nad Tisou; railway station (Jehlík \& Dostálek 2008).

Taraxacum serotinum (EN): 6; Surroundings of Trnava; railway embankments (Frantová 1947).

Tithymalus tommasinianus (DD): 8; Čierna nad Tisou; railway station; Vel'ké Kapušany; rail transhipment yard (Jehlík \& Dostálek 2008).

Tragus racemosus (VU): 6; Railway stations: Sl’ažany, Sered' (Eliáš 1979a).

Vaccaria hispanica subsp. grandiflora (CR): 6; Bratislava; main railway station (Eliáš 1979a).

Verbascum speciosum (EN): 6; Slopes along railway lines near Pezinok, Šenkvice, Báhoň, Trnava (Eliáš 1981). - Chotín; railway station (Eliáš, Sádovský in Králik 2009).

Veronica agrestis (EN): 6; Surroundings of Trnava; freight railway stations (Frantová 1947).

Xanthium strumarium (VU): 6; Surroundings of Trnava; railway embankments, rail yard and freight railway stations (Frantová 1947). - 8; Čierna nad Tisou; railway station; Vel'ké Kapušany; rail transhipment yard (Jehlík \& Dostálek 2008).

\section{Discussion}

Fragmentation and degradation of native habitats resulting from the intensification of land-use practices are generally considered to be main processes in recent Central European landscape. They can have a pronounced effect on the distribution pattern of threatened species. Although these species mostly require special effort in conservation management, several of them are able to colonize new and secondary man-made habitats. The present study reinforced the theory that railway transport facilities as man-made habitats can create artificial but ecologically suitable conditions for the occurrence and further spreading of rare and threatened vascular plants. Several thermophilous species (such as Androsace elongata, Draba nemorosa, Erysimum marschallianum, Papaver dubium subsp. austromoravicum) grow mainly on stony, gravelly or sandy substrata of railway yards or on platforms. Some species (Erysimum wittmannii, Geranium lucidum, Sempervivum carpathicum) occur connected with railways exclusively due to a very close parallel occurrence in their natural habitats. Segetal species (e.g. Adonis aestivalis, Neslia paniculata, Papaver argemone) are also quite frequent due to the spreading of their seeds with cereals transported by trains. In general, traffic (mainly freight transport) has an important role in the extension of plant species - alien but also native ones. The same is also true for European river ports (Jehlík 1998, 2013). 
Some species (e.g. Dichodon viscidum, Vicia grandiflora) are spreading by the railway northwards. Cerastium semidecandrum - common species in the Pannonian area - was recorded in Northern Slovakia in railway stations only (cf. Letz \& Michalková 2012). Similarly, Aegilops cylindrica is spreading by the railway to the north (Eliáš et al. 2013).

Railway habitats often represent an adventive occurrence of some native species, now extinct in former localities - e.g. Aegilops cylindrica or Ceratocephala orthoceras (Eliáš et al. 2013; Májeková et al. 2013).

Despite regular elimination of vegetation in railway areas by chemical and mechanical treatment, railways and their facilities represent a place of conservation of rare and threatened species.

Acknowledgments: We are grateful to Dr. Pavol Mered'a jun. for providing of data to some species and to Doc. Katarína Mišíková for the identification of bryophytes. This study was supported by the grant agency VEGA, grants no. 2/0098/11 and $2 / 0008 / 13$.

\section{References}

Barkman J. J., Doing H. \& Segal S. 1964. Kritische Bemerkungen und Vorschläge zur quantitativen Vegetationsanalyse. Acta Bot. Neerl. 13: 394-419.

Borhidi A., Kevey B. \& Lendvai G. 2012. Plant communities of Hungary. 544 pp. Akadémiai Kiadó, Budapest.

Brandes D. 1983. Flora und Vegetation der Bahnhöfe Mitteleuropas. Phytocoenologia 11:31-115.

BRANDES D. 1993. Eisenbahnanlagen als Untersuchungsgegenstand der Geobotanik. Tuexenia 13: $415-444$.

BRANDES D. 2003. Contributions to the urban flora and vegetation of Strasbourg (France). (http://www.digibib. tu-bs.de/?docid=00001517, 26.6.2014)

Braun-Blanquet J. 1964. Pflanzensoziologie. Grundzüge der Vegetationskunde. Ed. 3. 865 pp. Springer, Wien.

Chater A. O. 1980. Carex L. In: T. G. Tutin (ed.). Flora Europaea, pp. 290-323. Cambridge University Press, Cambridge.

Chytrý M. \& Tichý L. 2003. Diagnostic, constant and dominant species of vegetation classes and alliances of the Czech Republic: a statistical revision. $231 \mathrm{pp}$. Masaryk University, Brno.

Chrtková A. 1988. Vicia L. In: L. Bertová (ed.). Flóra Slovenska IV/4, pp. 151-199. Veda, Bratislava.

Euı́Ǎs P. 1972. Nová lokalita Trifolium rubens L. v Tríbečskom pohorí a jej floristický a vegetačný ráz. Zpr. Čs. Bot. Společ. 7: 153-156.

Eliáš P. 1977. Poznámky k lokalitám Tribulus terrestris L. subsp. orientalis (Kern.) Dost. na železničných stanovištiach Slovenska. Zpr. Čs. Bot. Společ. 12: 127-129.

ELIÁŠ P. 1979a. Zriedkavejšie rastliny železničných komunikácií na západnom Slovensku I. Biológia 34: 67-70.

ELIÁš P. 1979b. Linario-Brometum tectorum na železničnej stanici Cífer (západné Slovensko). Biológia 34: 329333.

Elíśs P. 1979c. The association Conyzo-Cynodontetum dactyloni in western Slovakia, Czechoslovakia. Preslia 51: 349-362.
ELIÁŠ P. 1981. Zriedkavejšie rastliny železničných komunikácií na západnom Slovensku II. Biológia 36: 73-77.

Eliáš P. \& FerÁKová V. 1999. Tribulus terrestris L. In: J. Čeňovský, V. FerÁková, J. Holub, Š. Maglocký \& F. ProchÁzKA. Červená kniha ohrozených a vzácnych druhov rastlín a živočíchov SR a ČR, Vol. 5. Vyššie rastliny, p. 382. Príroda, Bratislava.

Eliáš P. jun. (ed.). 2010. Zaujímavejšie floristické nálezy. Bull. Slov. Bot. Spoločn. 32: 275-281.

EuıÁš P. jun. 2011a. Geranium purpureum Vill. - new alien species to the Slovak flora. Thaiszia 21: 21-28.

EuıÁš P. jun. (ed.) 2011b. Zaujímavejšie floristické nálezy. Bull. Slov. Bot. Spoločn. 33: 103-109.

Eliáš P. jun. (ed.). 2012a. Zaujímavejšie floristické nálezy. Bull. Slov. Bot. Spoločn. 34: 103-113.

Eliáš P. jun. 2012b. Herniaria L. In: K. Goliašová \& E. Michalková (eds.). Flóra Slovenska VI/3, pp. 107119. Veda, Bratislava.

EliÁš P. jun. (ed.). 2013. Zaujímavejšie floristické nálezy. Bull. Slov. Bot. Spoločn. 35: 214-224.

Eliáš P. jun. (ed.). 2014. Zaujímavejšie floristické nálezy. Bull. Slov. Bot. Spoločn. 36: 96-107.

Eliáš P. jun., DítĚ D., Eliašová M. \& Ďurišová L. 2013. Distribution and origin of Aegilops species in Slovakia. Thaiszia 23: 117-129.

Eliáš P. jun., DítĚ D., Kliment J., HrivnÁK R. \& FerákovÁ V. 2014. Red list of ferns and flowering plants of Slovakia, 4th edition (November 2013). Biologia (subm.).

FerÁKOvé V. 1977. The genus Lactuca L. in Europe. 124 pp. Univerzita Komenského v Bratislave.

FerÁkovÁ V. \& JAVORČ́́KOVÁ D. 1974. Floristische Angaben von der Stadt Bratislava und ihrer Umgebung. I. Acta Fac. Rerum Nat. Univ. Comen., Bot. 22: 115-22.

Feráková V., MaglockÝ Š. \& Marhold K. 2001. Červený zoznam paprad'orastov a semenných rastlín Slovenska. In: D. Baláž, K. Marhold \& P. Urban (eds). Červený zoznam rastlín a živočíchov Slovenska, pp. 44-77. Ochr. Prír. 20 (Suppl.).

FrantovÁ J. 1947. Plevelová, ruderálna a adventívna flóra okolia Trnavy. Prírodovedný sborník 3-4: 153-248. 
FuTÁK J. 1943. Kremnické hory. Štúdia geobotanickofloristická. 135 pp. Matica Slovenská, Turčiansky Sv. Martin.

FutÁk J. 1980. Fytogeografické členenie. In: E. MAzúR (ed.). Atlas Slovenskej socialistickej republiky, p. 88. Slovenská akadémia vied, Slovenský úrad geodézie a kartografie, Bratislava.

FutÁK J. 1982a. Adonis L. In: J. FutÁK \& L. Bertová (eds.). Flóra Slovenska III, pp. 252-260. Veda, Bratislava.

FutáK J. 1982b. Linum L. In: J. FutÁK \& L. BertovÁ (eds.). Flóra Slovenska III, pp. 512-533. Veda, Bratislava.

FutÁk J., JASIČOvÁ M. \& SCHIDLAY E. 1966. Flóra Slovenska II. 352 pp. Vydavatel'stvo Slovenskej akadémie vied, Bratislava.

Galera H., Sudnik-Wójcikowska B., Wierzbicka M., JarzyNA I. \& WiŁKOMiRski B. 2014. Structure of the flora of railway areas under various kinds of anthropopression. Polish Bot. J. 59 (in press, DOI: 10.2478/ pbj-2014-0001)

HADINEC J. 2014. Geranium rotundifolium. In: J. HADINEC \& P. Lustyk P. (eds.). Additamenta ad floram Reipublicae Bohemicae. XII. Zprávy Čes. Bot. Společ. 49: 136.

HendRych R. \& Chrtek J. 1964. Ad districtum oppidi Modrý Kameň in Slovacia additamenta florographica. Acta Univ. Carol. Biol. 1964: 1-59.

Hohla M., Kleesadl G. \& Melzer H. 2005. Neues zur Flora der oberösterreichischen Bahnanlagen. Beitr. Naturk. Oberösterreichs 14: 147-199.

Holub J. \& KmeŤová E. 1988. Chamerion (Rafin.) Rafin. In: L. Bertová (ed.). Flóra Slovenska IV/4, pp. 432-440. Veda, Bratislava.

HörandL E. 1994. Systematik und Verbreitung von Papaver dubium L. s. 1. in Österreich. Linzer Biol. Beitr. 26: 407-435.

HrivnÁK R., GÖMÖRY D. \& CVAChOvÁ A. 2006. Inter-annual variability of the abundance and morphology of Dactylorhiza majalis (Orchidaceae - Ordchideae) in two permanent plots of a mire in Slovakia. Phyton (Horn) 46: 27-44.

Hrouda L. 1999. Chorologický přehled zástupců rodu Saxifraga $\mathrm{v}$ České republice a na Slovensku. Preslia 70: 289-301.

Jalas J. \& SuOMinen J. (eds.). 1994. Atlas Florae Europaeae 10. Cruciferae (Sisymbrium to Aubrieta). 224 pp. The Committee for Mapping the Flora of Europe and Societas Biologica Fennica Vanamo, Helsinki.

JARolímeK I., Š́ıíK J., TichÝ L. \& KLiment J. 2008. Diagnostic, constant and dominant species of the higher vegetation units of Slovakia. In: I. JAROLÍMEK \& J. ŠiBíK (eds.). Diagnostic, constant and dominant species of the higher vegetation units of Slovakia, pp. 9-294.Veda, Bratislava.

JarolímeK I., Zaliberová M., Mucina L. \& MochnackÝ S. 1997. Rastlinné spoločenstvá Slovenska 2. Synantropná vegetácia. 420 pp. Veda, Bratislava.

JASIČOvÁ M. 1982. Geranium L. In: J. FutÁK \& L. BerTOVÁ (eds.). Flóra Slovenska III, pp. 475-504. Veda, Bratislava.

JASIČOVÁ M. \& FutÁK J. 1985. Saxifraga L. In: L. BertoVÁ (ed.). Flóra Slovenska IV/2, pp. 223-275. Veda, Bratislava.
JASIČOVÁ M. \& ZAHRADNíKOVÁ K. 1976. Organizácia a metodika mapovania rozšírenia rastlinných druhov v západnej tretine Slovenska. Biológia 31: 74-80.

JенLík V. (ed.). 1998. Cizí expanzivní plevele České republiky a Slovenské republiky. 506 pp. Academia, Praha.

JенLík V. 2013. Die Vegetation und Flora der Flusshäfen Mitteleuropas. 546 pp. Academia, Praha.

JeHLík J. \& DostÁLEK J. 2008. Influence of railway transport in the South-East of Slovakia on formation of adventive flora in Central Europe. Biodiv. Res. Conserv. 11-12: 27-32.

Jehlík V., Májeková J. \& Zaliberová M. 2013. New discovered adventive plants from eastern Slovakia. Thaiszia 23: 61-66.

Kącki Z., Czarniecka M. \& Swacha G. 2013. Statistical determination of diagnostic, constant and dominant species of the higher vegetation units of Poland. Monogr. Bot. 103: 1-271.

Kliment J., Bernátová D., DítĚ D., Janišová M., JarolímeK I., Kochjarová J., Kučera P., Obuch J., Topercer J., Uhlířová J. \& Zaliberová M. 2008. Paprad'orasty a semenné rastliny. In: J. KLimENT (ed.). Príroda Vel'kej Fatry. Lišajníky, machorasty, cievnaté rastliny, pp. 109-367. Vydavatel'stvo Univerzity Komenského, Bratislava.

Kliment J., Hrivnák R., Jarolímek I. \& Valachovič M. 2000. Cievnaté rastliny Drienčanského krasu. In: J. KLIMENT (ed.). Príroda Drienčanského krasu, pp. 97-150. ŠOP SR, Banská Bystrica.

KmeŤová E. 1993. Chamaepitys Hill. In: L. Bertová \& K. Goliašová (eds.). Flóra Slovenska V/1, pp. 187-191. Veda, Bratislava.

Kochuarová J. 2007. Floristicko-fytocenologické zaujímavosti z južného okraja Vel'kej Fatry. Bull. Slov. Bot. Spoločn. 29: 135-145.

KochJarová J. 2010. Flóra okolia Tornale (Zborník výsledkov 45. Floristického kurzu SBS a ČBS v Tornali, 2.-8. 7. 2006). Bull. Slov. Bot. Spoločn. 32, Suppl. 1: $1-79$.

KRÁLIK T. 2009. Divozel úhl'adný (Verbascum speciosum) nepôvodný druh našej flóry? Bull. Slov. Bot. Spoločn. 31: 21-34.

LETz R. 2002. Nomenclature of the Sempervivum montanum group (Crassulaceae) in the Carpathians. Phyton (Horn) 42: 109-115.

Letz D. R. 2012. Dichodon (Bartl. ex Rchb.) Rchb. In: K. Goliašová \& E. Michalková (eds.). Flóra Slovenska VI/3, pp. 280-291. Veda, Bratislava.

LETZ R. \& MARHOLD K. 1998. Multivariate morphometric study of the Sempervivum montanum group in the West Carpathians. Phyton (Horn) 38: 323-336.

Letz D. R. \& Michalková E. 2012. Cerastium L. In: K. Goliašová \& E. Michalková (eds.). Flóra Slovenska VI/3, pp. 291-388. Veda, Bratislava.

Letz D. R., HrivNÁK R. \& SlezÁK M. 2013. Zaujímavé nálezy ruderálnych, segetálnych a zavlečených cievnatých rastlín z územia stredného Slovenska II. Bull. Slov. Bot. Spoločn. 35: 127-139.

Lososová Z., OtÝPKová Z., SÁdlo J. \& LÁNíková D. 2009. Jednoletá vegetace polních plevelů a ruderálních stanovišt'. In: M. Chytrý (ed.). Vegetace České 
republiky 2. Ruderální, plevelová, skalní a sut'ová vegetace, pp. 73-205. Academia, Praha.

Maglocký Š. 1978. Filagini-Vulpietum Oberd. 1938 in den Kleinen Karpaten. Acta Bot. Slov. Acad. Sci. Slov., Ser. A, 3: 299-304.

Májeková J., Zaliberová M., Šı́ík J. \& Klimová K. 2010. Changes in segetal vegetation in the Borská nížina Lowland (Slovakia) over 50 years. Biologia 65: 465-478.

Májeková J., Zaliberová M. \& Jehlík V. 2013. Extinct species Ceratocephala testiculata (Crantz) Besser rediscovered in Slovakia after 44 years. Thaiszia 23: 141-145.

Májeková J. \& Zaliberová M. 2014. Phytosociological study of arable weed communities in Slovakia. Tuexenia 34: 271-303.

Marhold K. \& HindáK F. (eds.). 1998. Checklist of nonvascular and vascular plants of Slovakia. $688 \mathrm{pp}$. Veda, Bratislava.

Medvecká J., Kliment J., Májeková J., Halada L', ZaliBerová M., Gojdičová E., Feráková V. \& Jarolímek I. 2012. Inventory of the alien flora of Slovakia. Preslia 84: 257-309.

Meusel H., Jäger E., Rauschert S. \& Weinert E. 1978. Vergleichende Chorologie der zentraleuropäischen Flora. II. Text xi+418 pp., Karten pp. 259-421. Gustav Fischer Verlag, Jena.

Michalková E. 2002. Erysimum L. In: K. Goliašová \& H. ŠíPošovÁ (eds.). Flóra Slovenska V/4, pp. 182-225. Veda, Bratislava.

Mráz P. 2002. Neslia Desv. In: K. GoliašovÁ \& H. Š́́íošovÁ (eds.). Flóra Slovenska V/4, pp. 588-593.Veda, Bratislava.

Mucina L. 1987. The ruderal vegetation of the northwestern part of the Podunajská nížina Lowland. Folia Geobot. Phytotax. 22: 1-23.

Peniašteková M. 1993. Dalanum Dostal. In: L. Bertová \& K. GoliašovÁ (eds.). Flóra Slovenska V/1, pp. 226235, Veda, Bratislava.

Peniašteková M. \& Kliment J. 2002. Draba L. In: K. GoliAšovÁ \& H. Š́́íošovÁ (eds.). Flóra Slovenska V/4, pp. 500-540.Veda, Bratislava.

ReIsCh C. 2007. Genetic structure of Saxifraga tridactylites (Saxifragaceae) from natural and man-made habitats. Conserv. Genet. 8: 893-902.

Schidlay E. 1944. Š́renie sa rastlín Erucastrum nasturtiifolium a E. gallicum na Slovensku. (Príspevok k flóre Slovenských železníc). Techn. Obzor Slov., Prírod. Príl. 1944: 49-55.

Š́́pošová H., KubÁt K. \& Bernátová D. 2002. Papaver L. In: K. GoliašovÁ \& H. Š́́pošovÁ (eds.). Flóra Slovenska V/4, pp. 25-60. Veda, Bratislava.
SLAvík B. 1986. Epilobium dodonaei Vill. in der Tschechoslowakei. Preslia 59: 307-338.

SlezÁk M., Letz D. R., Hrivnák R., VlčKo J., Turis P. \& BLANÁR D. 2012. Aktuálne poznatky o výskyte niektorých zriedkavejších cievnatých rastlín na území stredného Slovenska. Bull. Slov. Bot. Spoločn. 34: 19-44.

Smatana M. 2004. Príspevok k poznatkom o rozšírení papradí, prasličiek a plavúňov v okolí Považskej Bystrice. Bull. Slov. Bot. Spoločn. 26: 45-52.

Smejkal M. 1961. Taxonomická studie druhu Ajuga chamaepitys (L.) Schreb. ampl. Briq. v Československu. Preslia 33: 386-398.

Štrba P. 2012. Petrorhagia (Ser.) Link. In: K. Goliašová \& E. Michalková (eds.). Flóra Slovenska VI/3, pp. 580-589. Veda, Bratislava.

SuTORÝ K. 2013. Floristické poznámky ke květeně Muráňské planiny a Slovenského krasu. Bull. Slov. Bot. Spoločn. 35: 25-27.

THIERs B. 2014 (continuously updated). Index Herbariorum: A global directory of public herbaria and associated staff. New York Botanical Garden's Virtual Herbarium. Available from: http://sweetgum.nybg.org/ ih/ (accessed: 2nd January 2014)

Tutin T. G. 1993. Flora Europaea. Volume 1: Psilotaceae to Platanaceae. Second edition. 629 pp. Cambridge University Press, Cambridge.

Valachovič M. 1990. Galeopsietum angustifoliae - ekologická a geografická diferenciácia, syntaxonomická revízia. Biológia 45: 61-70.

Valachovič M., OŤahelová H., Stanová V. \& Maglocký Š. 1995. Rastlinné spoločenstvá Slovenska 1. Pionierska vegetácia. 184 pp. Veda, Bratislava.

Wotavová K., Balounová Z. \& Kindlmann P. 2004. Factors affecting persistence of terrestrial orchids in wet meadows and implications for their conservation in a changing agricultural landscape. Biol. Conserv. 118: 271-279.

ZAHRADNíKOVÁ K. 1982. Zygophyllaceae. In: J. FUTÁK \& L. Bertová (eds.). Flóra Slovenska III, pp. 535-537. Veda, Bratislava.

Zaliberová M., Szabóová A., Kollár J., Magic D. \& KubíčEK F. 2008. Flóra. In: E. KALIVodovÁ (ed.). Flóra a fauna viatych pieskov Slovenska, pp. 26-55. Veda, Bratislava.

Zaliberová M. \& MájeKová J. 2014. Poznámky k prvému nálezu Geranium purpureum Vill. na Slovensku a rozšírenie druhu na železničných staniciach Záhoria (západné Slovensko). Bull. Slov. Bot. Spoločn. 36 (in press). 